\section{A MINIATURE SOLID PROPELLANT ROCKET MOTOR*}

\author{
M. C. Grubelich, M. Hagan, E. Mulligan \\ Sandia National Laboratories \\ Albuquerque, NM 87185-1453
}

\section{ABSTRACT}

A miniature solid-propellant rocket motor has been developed to impart a specific motion to an object deployed in space. This rocket motor effectively eliminated the need for a cold-gas thruster system or mechanical spin-up system. A low-energy igniter, an $\mathrm{XMC} 4397$, employing a semiconductor bridge was used to ignite the rocket motor. The rocket motor was ground-tested in a vacuum tank to verify predicted space performance and successfully flown in a Sandia National Laboratories flight vehicle program.

\section{INTRODUCTION}

In order to impart a specific motion to a space-deployed object, a cold-gas thruster, mechanical system, or solid propellant rocket motor can be used. Cold-gas systems exhibit low energy density and in general cannot provide high-force, short-duration thrust profiles. Mass-ejecting mechanical systems also exhibit a low energy density as well as producing space debris. A solid propellant rocket motor can reliably produce a specific force profile and generate a desired total impulse in a volumetrically and mass-efficient package. A Sandia flight vehicle required a rocket motor to produce a total impulse of approximately $0.61 \mathrm{lb}_{\mathbf{r}} \mathrm{s}$ with a thrust duration of $50 \mathrm{~ms}$.

Small low-thrust short-burn duration rocket motors pose a unique set of design and testing problems. Specifically, small solid-propellant (approximately $0.002 \mathrm{lb}_{\mathrm{m}}$ ) rocket motors with short-burn durations (approximately $100 \mathrm{~ms}$ ) pose ignition, manufacturing, and testing difficulties. Typical igniter output can be excessive given the small size of the solid propellant rocket motor. For precise impulse delivery, the output of the igniter can contribute significantly to the overall impulse of the rocket motor. From a manufacturing and production standpoint, the machining tolerances of both the rocket motor hardware and solid propellant become critical due to the small size of the components. Finally, high frequency response instrumentation is required in order to adequately

\footnotetext{
* This work was supported by the United States Department of Energy under Contract DE-AC04-94AL85000.
}

\section{SANOY7-165\% \\ CONF.970\%27--2}

measure operating pressure and thrust. A simple "back of the envelope" design methodology will be discussed and compared with the results of experimental testing.

\section{DISCUSSION}

The design requirements for the rocket motor were a delivered total impulse of $0.61 \mathrm{lb}_{\mathrm{f}}$-s with a thrust duration of $50 \mathrm{~ms}$. An XMC4397 was specified as and explosive safety. The XMC4397 employed a $\mathbf{C}$ ) semiconductor bridge as the ignition element to ignite an $88 \mathrm{mg}$ charge of titanium subhydride/potassium perchlorate. Given this initial requirement, a simple design approach may be taken. A motor operating chamber pressure of $1000 \mathrm{psi}$ was selected since most "off-the-shelf" composite propellants have published experimental burn rate and specific impulse data at 1000 psia. Next a propellant grain geometry was determined and a propellant selected. This is an iterative procedure based on propellant burn rate, specific impulse, density, and grain geometry. A driving parameter was a geometry which could be easily fabricated and would provide a nearly constant propellant burn surface area in order to maintain a steady thrust profile. A center-perforated cylindrical grain inhibited on the outside and on one end, 0.50 inches long by 0.50 inches $O D$ and 0.38 inches $\mathrm{ID}$ was designed. Given this web thickness and propellant volume, a propellant with a nominal burn rate of 1.2 inches per second at 1000 psia with a specific impulse of $244 \mathrm{lb}_{\mathrm{f}} \mathrm{s} / \mathrm{lb}_{\mathrm{m}}(1000 \mathrm{psia}$ expanded to $14.7 \mathrm{psia})$ and a density of $0.0621 \mathrm{Ib}_{\mathrm{m}} / \mathrm{in}^{3}$ was selected.

With an average thrust of $12.2 \mathrm{lb}_{\mathrm{f}}$ (total impulse divided by time) and a defined operating pressure of 1000 psia, the nozzle throat diameter can be found from the following equation:

$$
\mathrm{F}=\mathrm{C}_{\mathrm{F}} \mathrm{A}_{\mathrm{t}} \mathrm{P}_{\mathrm{C}}
$$

where $F$ is the thrust, $C_{F}$ is the thrust coefficient, $A_{t}$ is the throat cross-sectional area, and $P_{C}$ is the chamber pressure. Using the graph in Figure 1 with an area ratio of four (the nozzle expansion ratio of the rocket motor was limited by length and mass constraints), the calculated value for the throat diameter is 0.1 inches. In order to ignite the propellant without overshooting the design operating pressure with the output from the $\mathrm{XMC4397,} \mathrm{the} \mathrm{igniter} \mathrm{output} \mathrm{is} \mathrm{throttled} \mathrm{by} \mathrm{firing} \mathrm{the}$ igniter into a small plenum which then discharges through a metering orifice into the propellant combustion chamber. The plenum and orifice serve

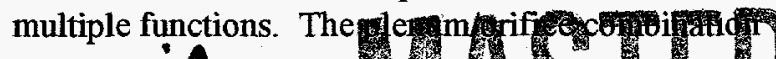

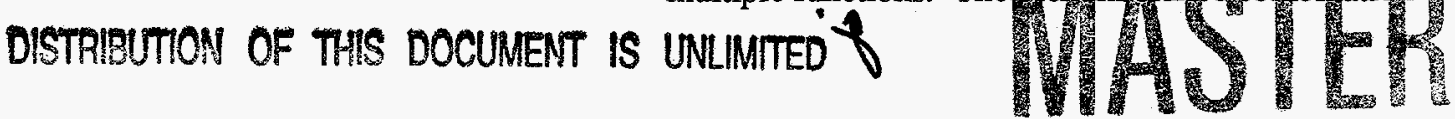


increases the combustion efficiency of the titanium subhydride/potassium perchlorate igniter mixture, the peak output pressure of the igniter is attenuated, the pressure and thermal impulse duration is extended, and the igniter's closure disc is prevented from entering the combustion chamber where it would be ejected into space. Orifice sizing is critical to assure reliable ignition of the propellant without grossly overshooting the design operating pressure. XMC4397 output pressure, thrust contribution, and total impulse are measured by firing the XMC4397 in an inert instrumented rocket motor. (See the graphs in Figures 2,3 , and 4.)

Once an acceptable orifice size is selected, the mock propellant is replaced with live propellant and the rocket motor can be test-fired (see Figure 5). Since space performance was critical, the rocket motor was test-fired in a vacuum tank (see Figure 6). The vacuum tank volume was selected to minimize the effects from pressure rise on the rocket motor as a result of the discharge of propellant combustion gases into the tank. Instrumentation with sufficient frequency response is required to obtain appropriate data as a result of the rapid event associated with the firing of the XMC4397. A high-frequency-response piezoelectric load cell and piezoresistive pressure transducer were used to obtain thrust, combustion chamber pressure, and total impulse history (see Figures 7, 8, and 9). Subsequent design changes reduced the ignition overpressure produced by the igniter. Small concentricity and eccentricity errors in the machined propellant grain produce a propellant sliver at burnout which results in a slow thrust tailoff rather than a sharply defined thrust cutoff This extends the burn duration of the rocket motor. The reduced thrust over that which was calculated is a result of the thrust tailoff and system losses. Chamber pressure and total impulse are in good agreement with the calculated values, although the total impulse includes the contribution from the igniter.

\section{CONCLUSION}

A simple back-of-the-envelope rocket motor design has been shown and experimentally demonstrated. Given a propellant bum rate, specific impulse, and density, and by designing grain geometries with a nearly constant propellant burning surface area, prototype rocket motors can be quickly developed and their performance verified. This simple technique provides the engineer with a rapid method of prototyping rocket motors.

\section{REFERENCES}

G. P. Sutton, Rocket Propulsion Elements, SixthEdition, John Wiley \& Sons, 1992. 


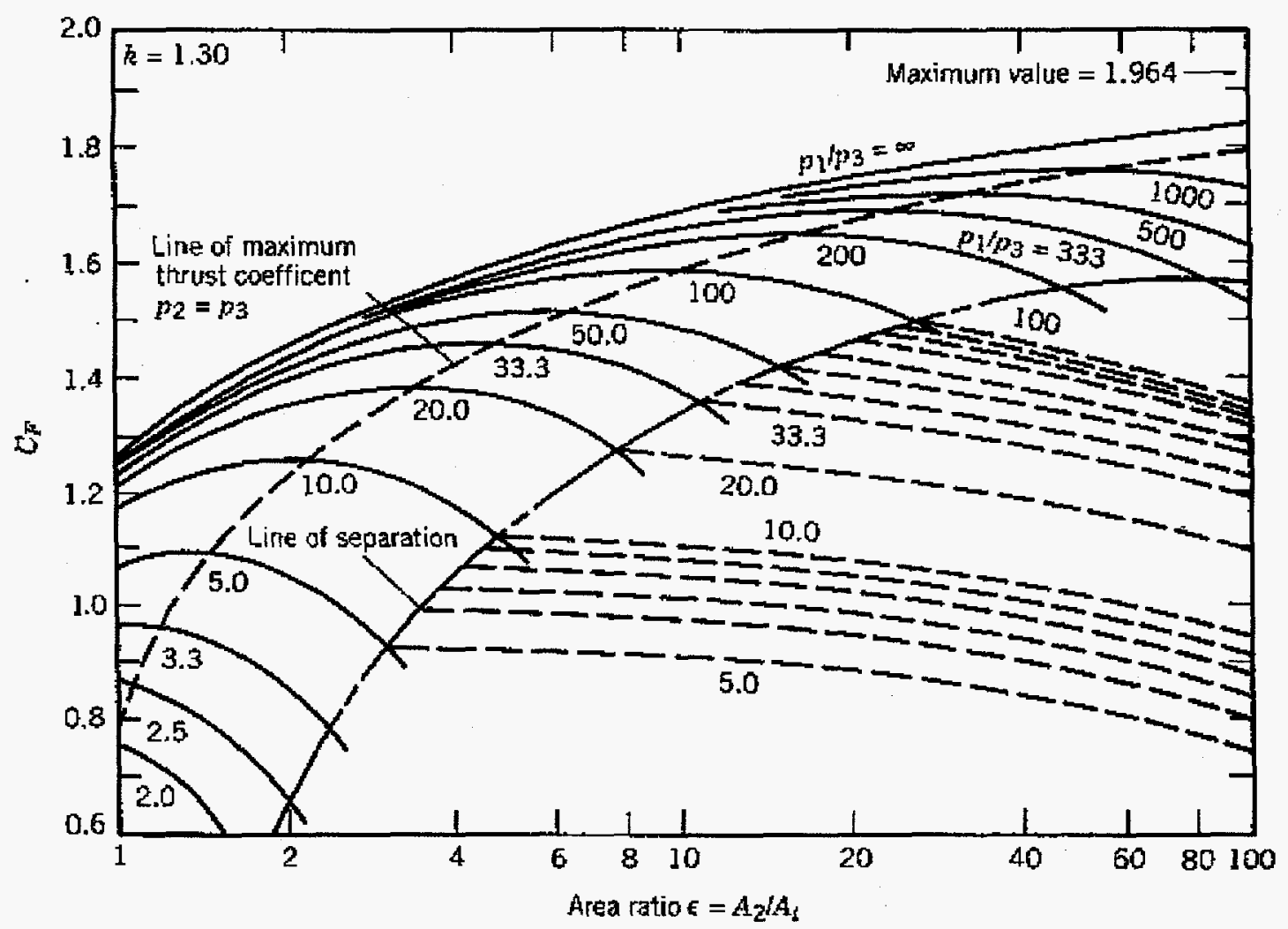

Figure 1. Thrust coefficient $C_{F}$ versus nozzle area ratio for $k=1.30$ (from Sutton 1992).

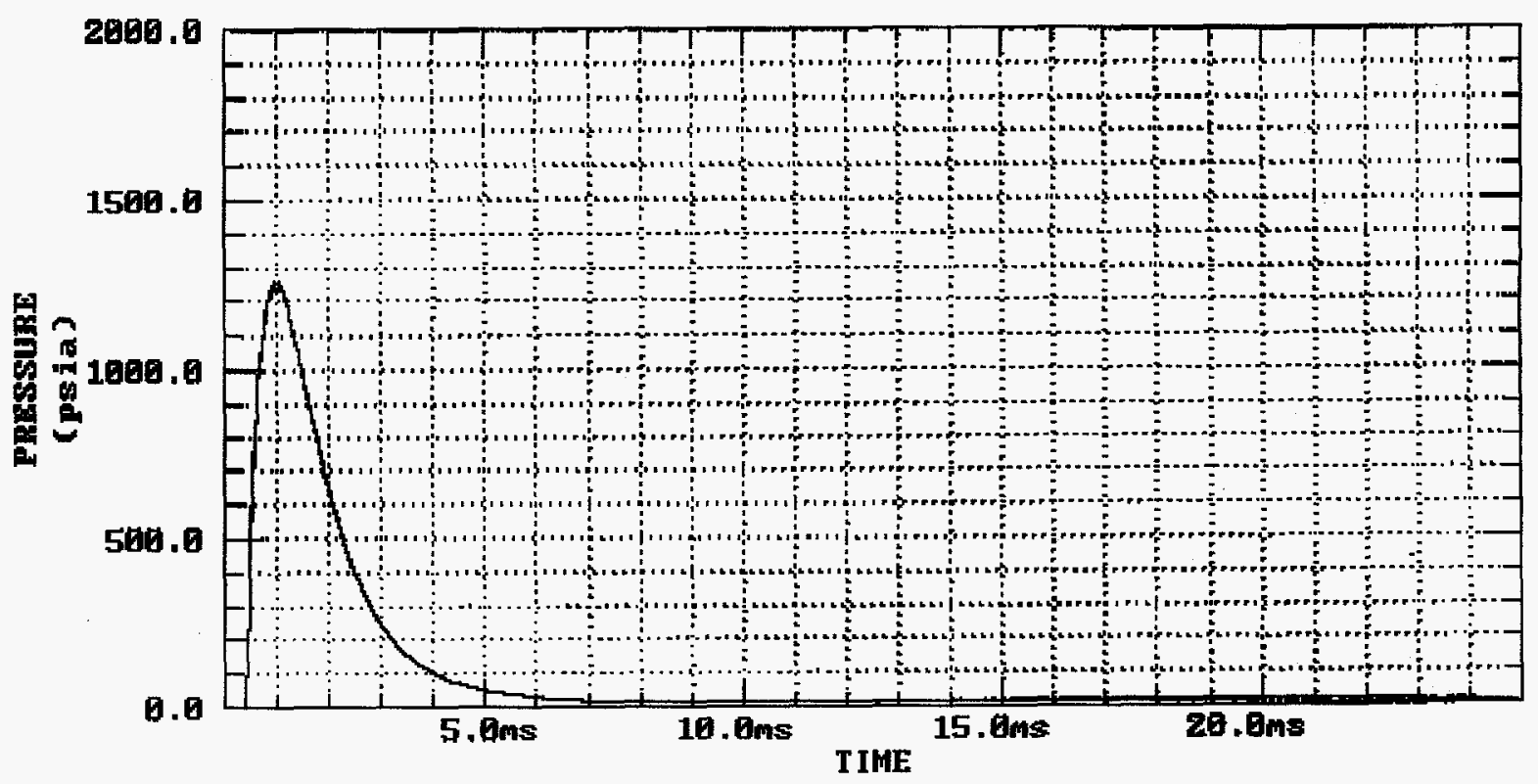

Figure 2.. Igniter pressure versus time. 


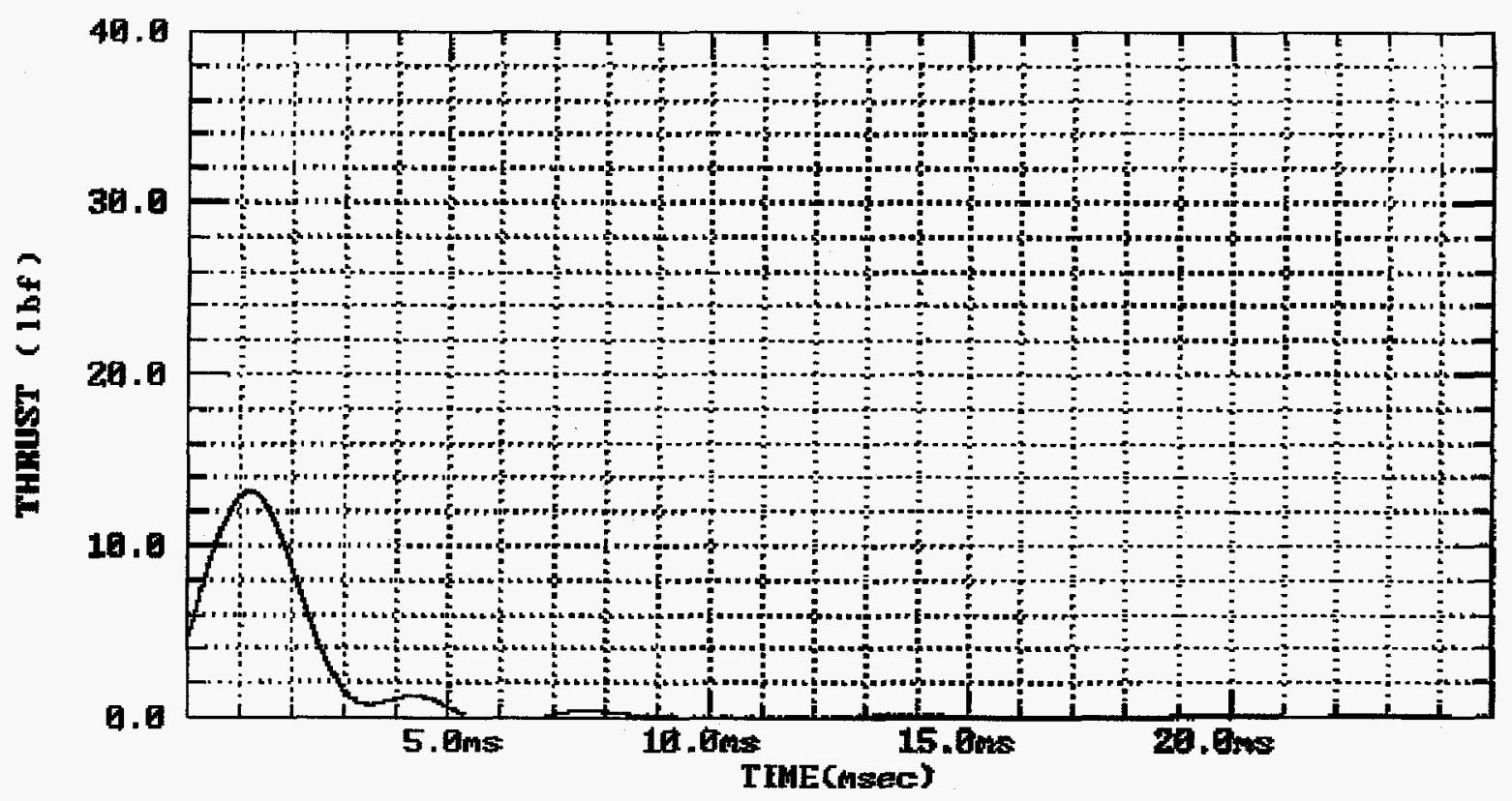

Figure 3. Igniter thrust versus time.

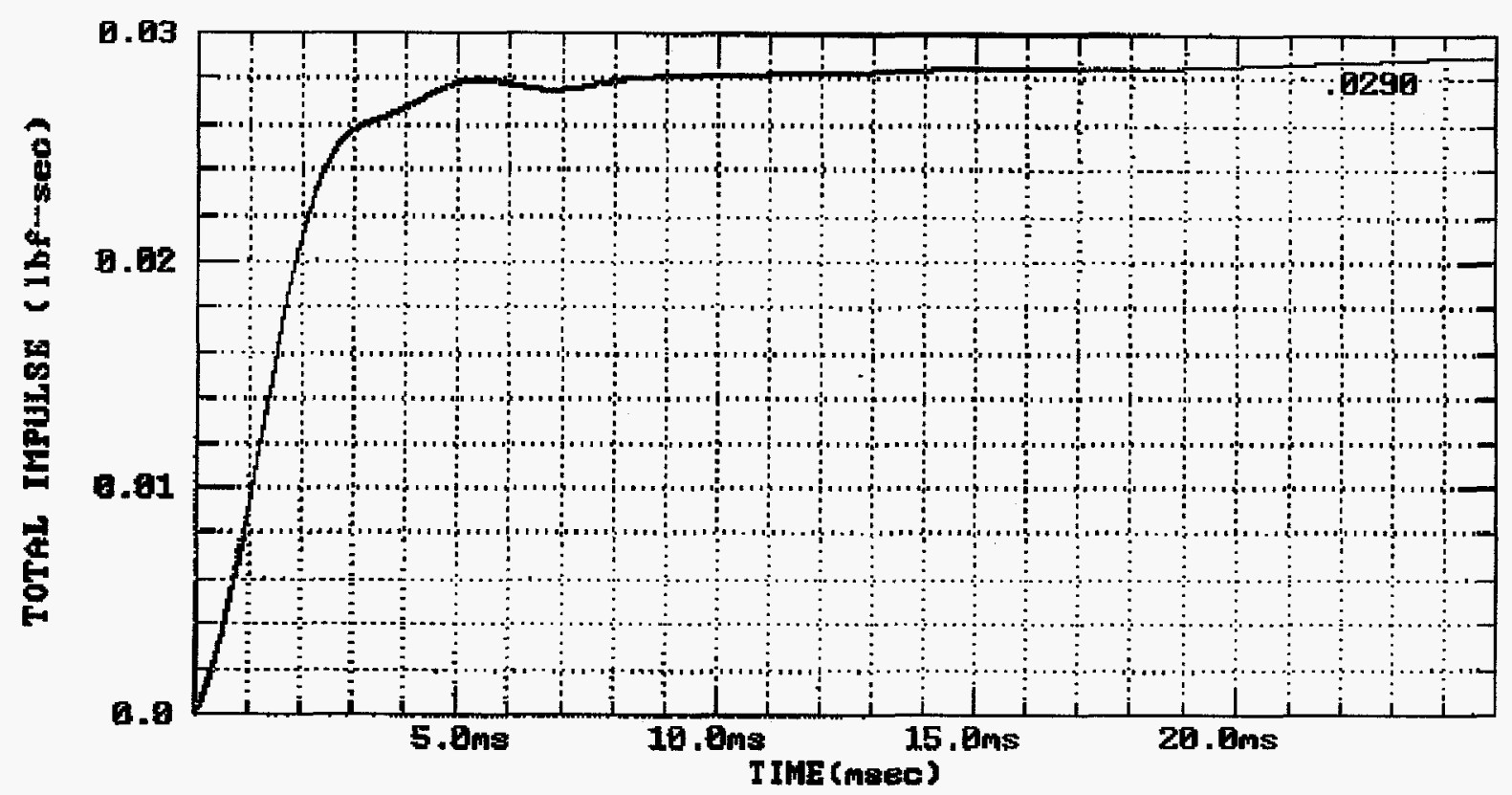

Figure 4. Igniter total impulse versus time. 


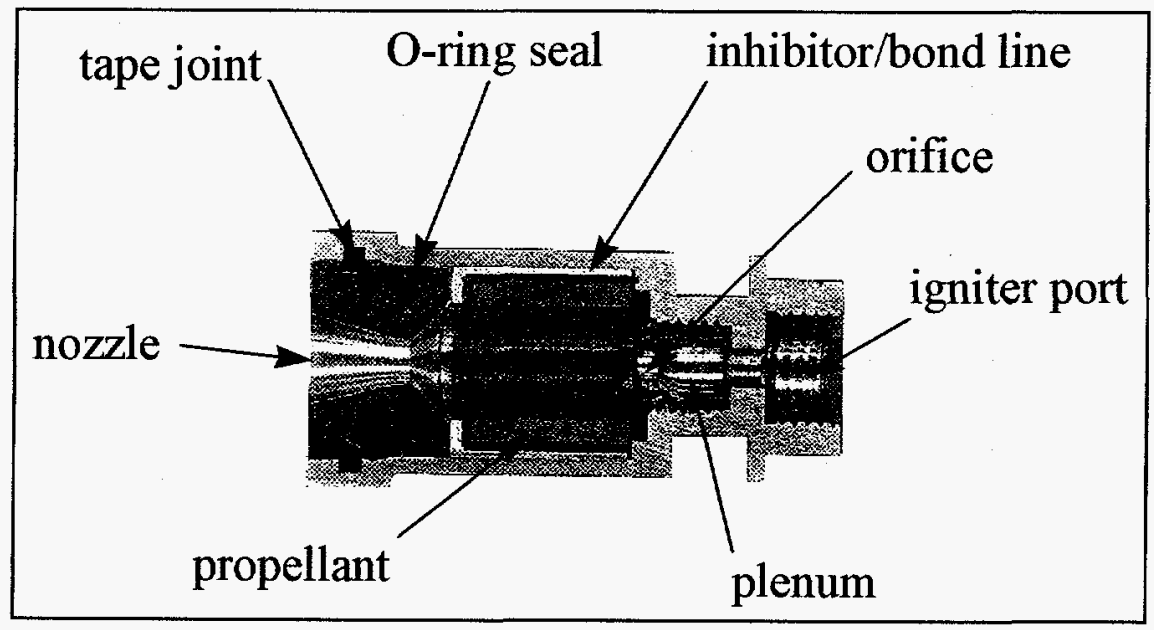

Figure 5. Miniature rocket motor.

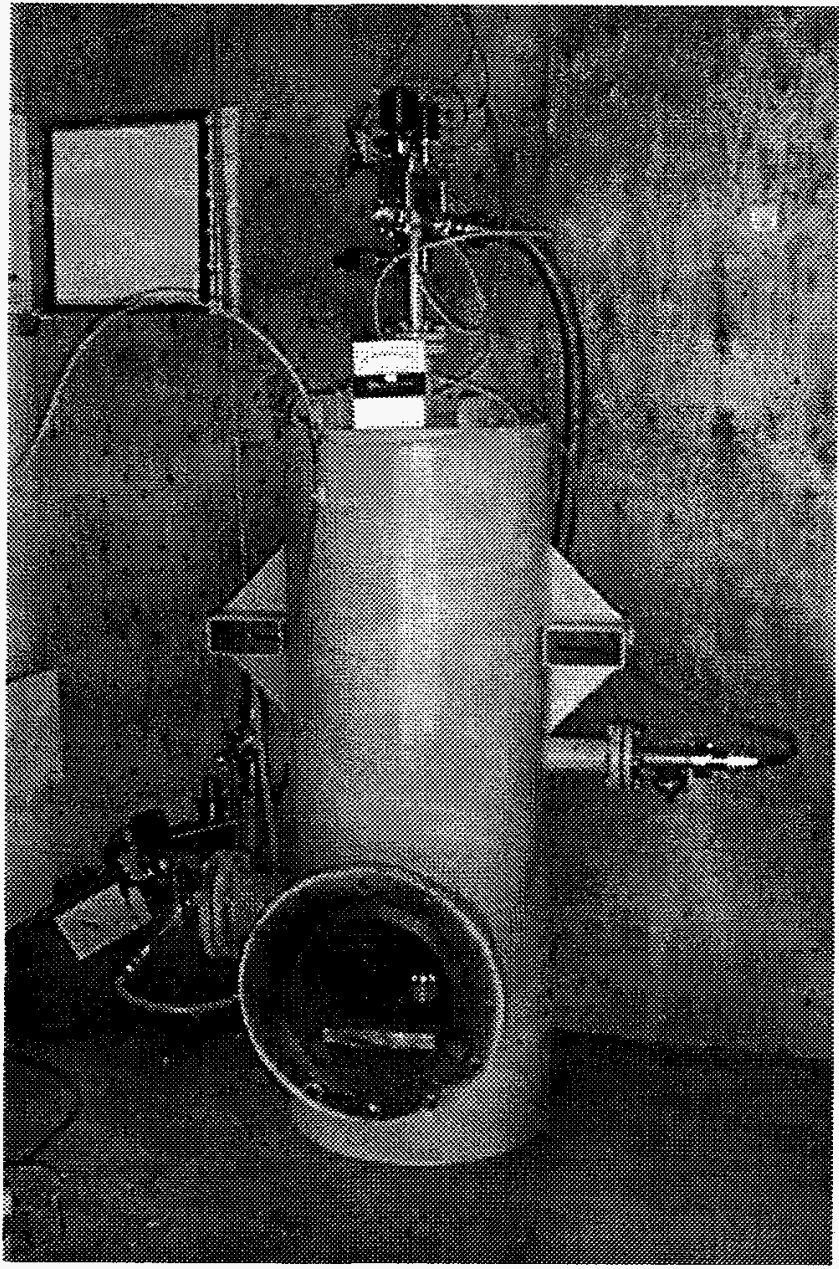

Figure 6. Vacuum tank. 


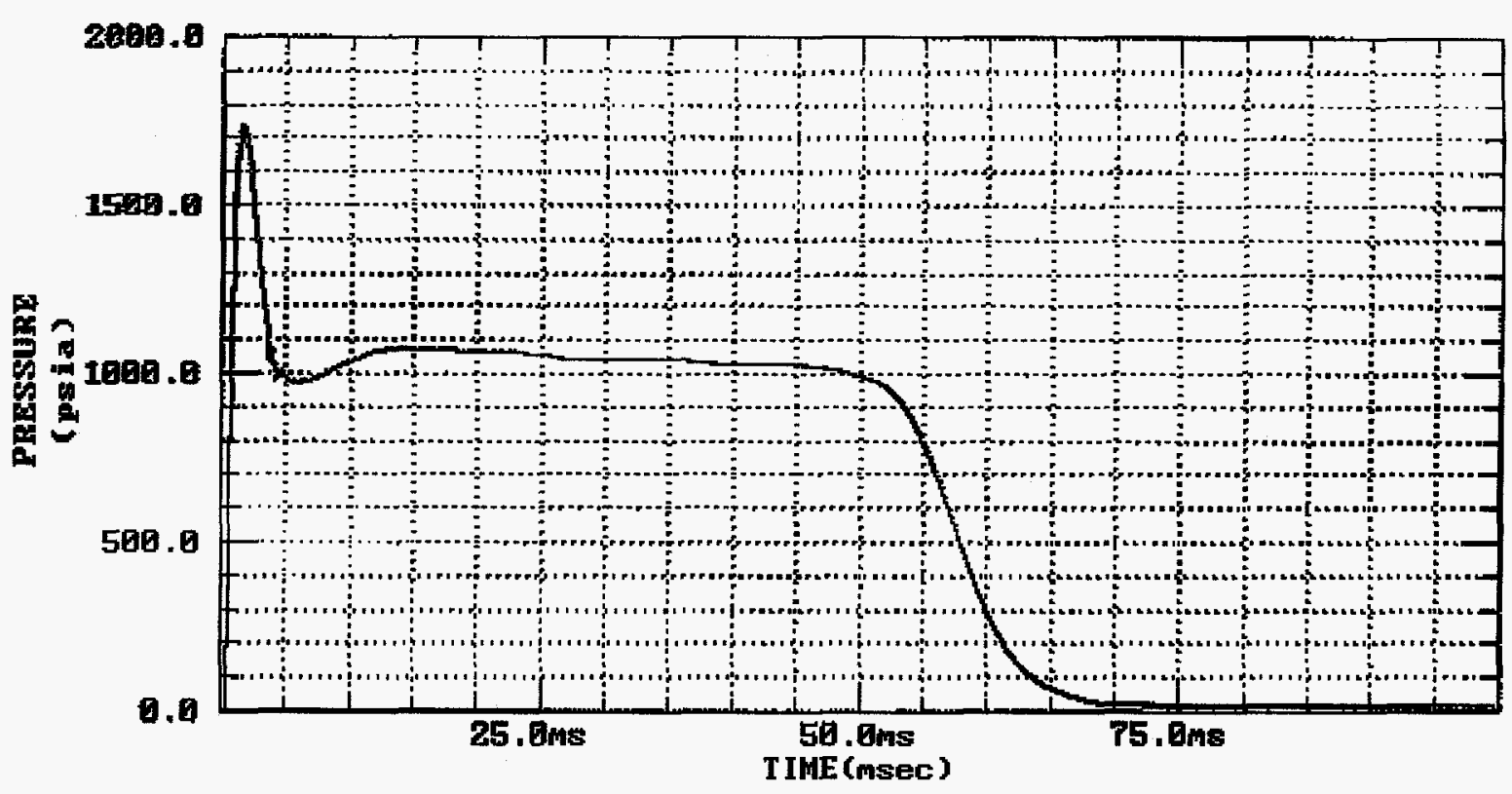

Figure 7. Motor pressure versus time.

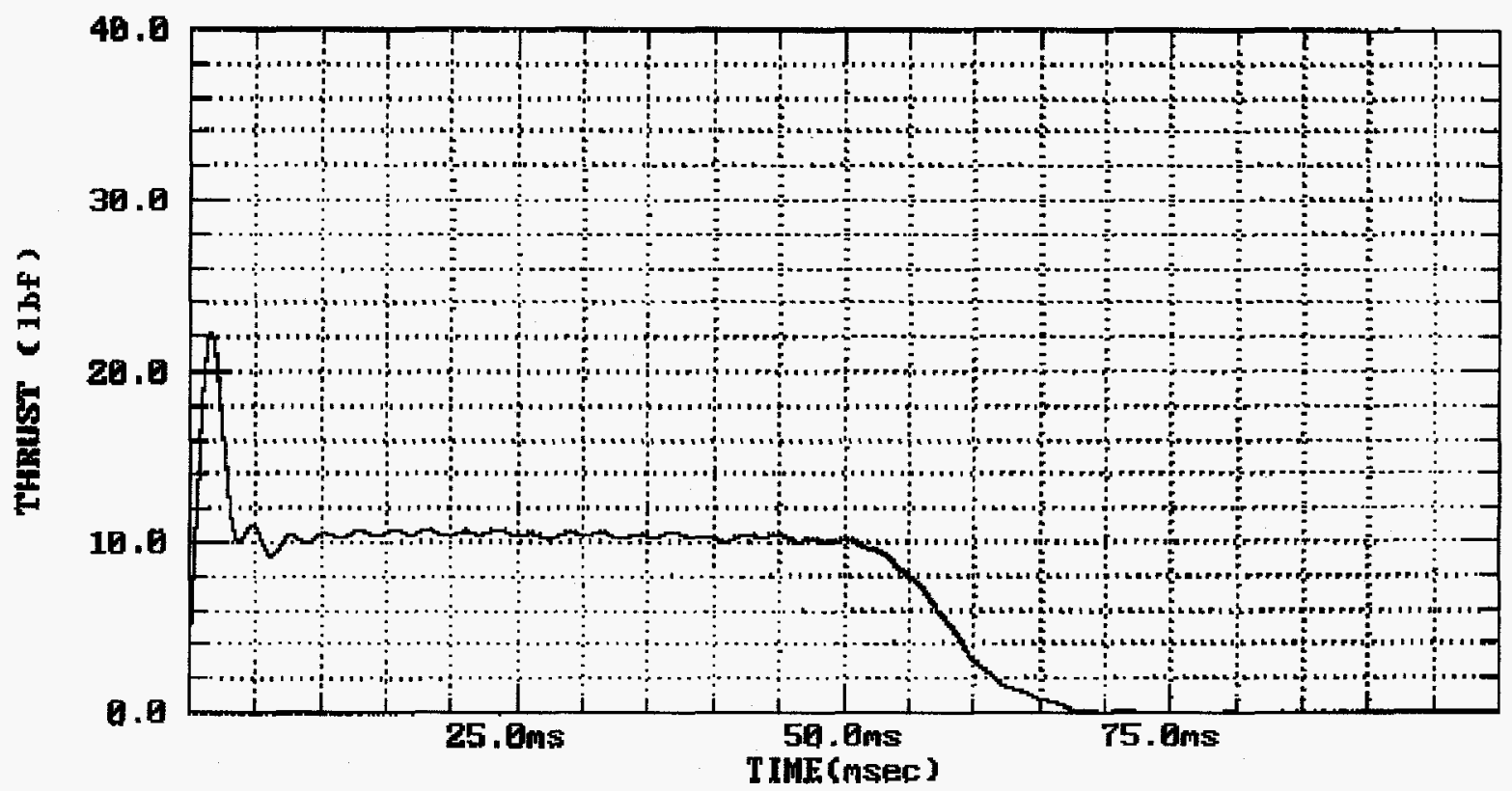

Figure 8. Motor thrust versus time. 


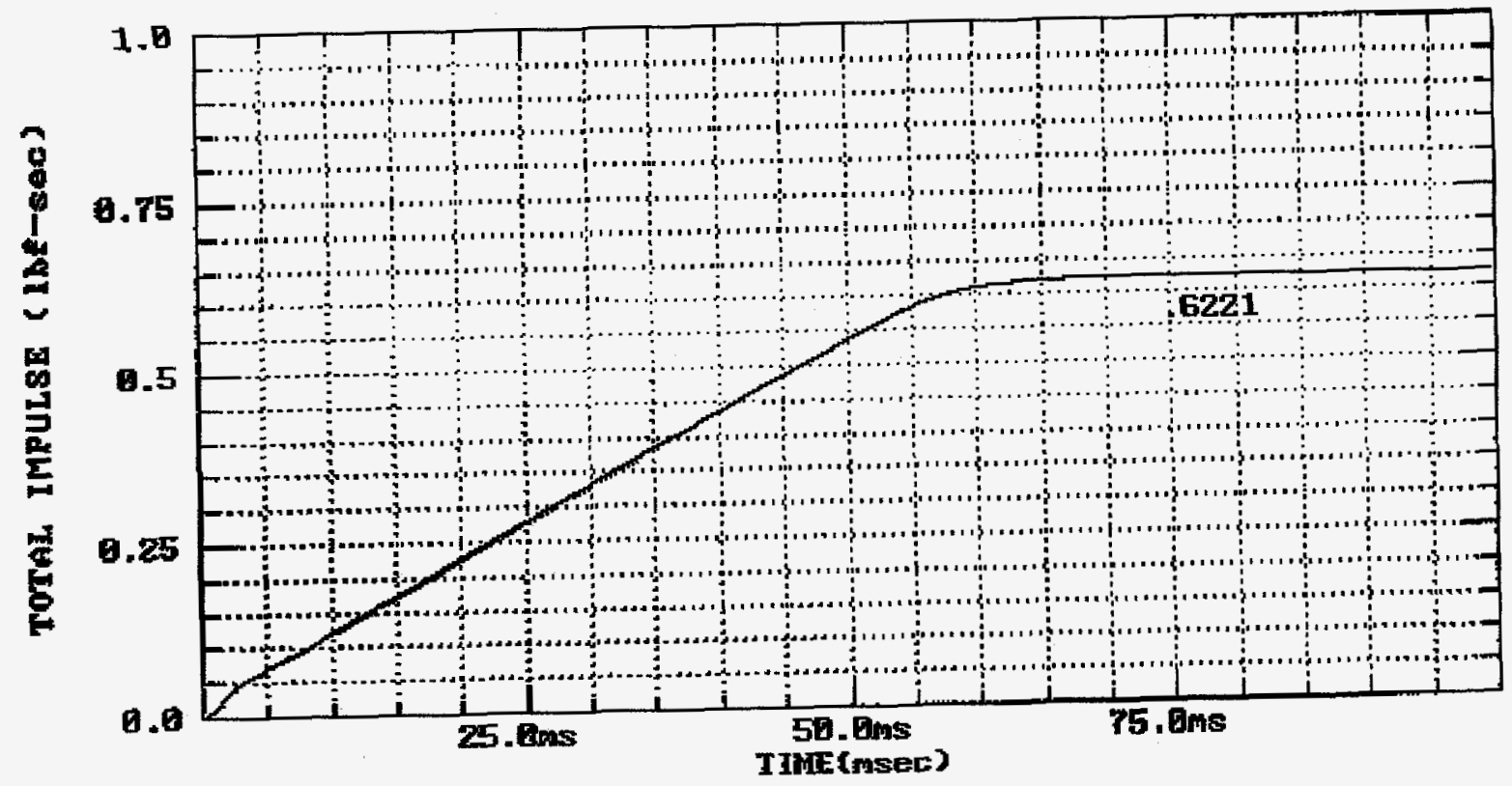

Figure 9. Motor total impulse versus time.

This report was prepared as an account of work sponsored by an agency of the United States Government. Neither the United States Government nor any agency thereof, nor any of their empleyees, makes any warranty, express or implied, or assumes any legal liability or responsibility for the accuracy, completeness, or usefulness of any information, apparatus, product, or process disclosed, or represents that its use would not infringe privately owned rights. Reference herein to any specific commercial product, process, or service by trade name, trademark, manufacturer, of otherwise does not necessarily constitute or imply its endorsement, recommendation, or favoring by the United States Government or any agency thereof. The views and opinions of authors expressed herein do not necessarily state or reflect those of the United States Government or any agency thereof. 


\section{DISCLAMMER}

Portions of this document may be illegible in electronic image products. Images are produced from the best available original docoument. 